\title{
Alternative and pollution-free way of producing water
}

\author{
O. Ivashchenko, \\ doctor of agricultural sciences Sciences, professor, academician of NAAS \\ Institute of Bioenergetic Cultures and Sugar Beet NANA \\ O. Ivaschenko \\ doctor of agricultural sciences, p. N. with. \\ Institute of Plant Protection of NAAS
}

The purpose. To assess an opportunities of alternative way of deriving quality water from aerosphere. Methods. Analytical, calculation. Results. The share of fresh water on the planet makes $2,5 \%$ of its general amount. Fresh water is concentrated mainly in ice cellars. Only $0,1 \%$ of fresh water is in circulation. Almost $86 \%$ of all water volume that enters in aerosphere of the planet is water of oceans and seas. Accordingly 73,5 thousand $\mathrm{km} 3$ make volumes of vaporization from the surface of land. 36 thousand $\mathrm{km} 3$ of them are water volumes, which enter in air as the result of processes of thermal control of plants (transpiration). The majority of regions of the country receive water from aerosphere as the result of advection (transference) of water vapour from open spaces of oceans, seas, surfaces of fresh ponds in depth of continent and its storin evapotranspiration or snow. Conclusions. Power expenditures for deriving water can be diminished in some times at use of system of heat exchangers with low temperature of substrate (cool water, rock, etc.), which effectively absorb warm from air and warm change of phase of vapour into fluid.

Key words: water, air, condensation, energy.

Relevance of the problem. The value of water as a mandatory component of life is well-known.

No less important is the value and irreplaceability of water. Let's remind some of the properties of water - a substance which in a liquid aggregate state is a transparent fluid that does not smell ortaste.

The spatial model of the water molecule has a V-like shape and is a dipole [1].

Water is a universal solvent and there is no substance that would dissolve completely in water [2].

Water is an active reagent of a large number of chemical and biochemical reactions. Water - an important transport function - the transfer of dissolved substances in living organisms [3].

Due to high heat capacity, water is an effective thermoregulator, both in nature and in organisms, from cells to complex biological systems [4].

The very nature of water and its properties are unique. Water has no analogues among other substances present on our planet. Under conditions of heating, water, in the form of a liquid, expands and reduces specific density. In cooling, water reduces its volume, increases the specific density, but only up to $4 \mathrm{oC}$. The subsequent cooling results in the expansion of water. Already at $0 \mathrm{o} C$ the water passes into a crystalline solid state and has a positive buoyancy water. Already at $00 \mathrm{C}$ the water passes into a crystalline solid state and has a positive buoyancy [5]. Ice on the surface of the reservoirs serves as a thermal insulator in nature, protects the thickness of liquid water from cooling and freezing, and thus ensures the survival of aquatic organisms from death in the winter.

In tissues of plants that actively carry out growth processes, the water content traditionally exceeds $80 \%$ of their mass [6,7]. A lot of water and in the human body. In the tissues of the brain, the proportion of water exceeds $80 \%$. Water covers more than $2 / 3$ of the surface of our planet, but it is basically salty water [8].

The share of fresh water on the planet is only $2.5 \%$ of its total quantity. Fresh water is mainly concentrated in the glaciers of Antarctica, about. Greenland and other polar islands in rivers and lakes [9]. 
By the level of providing fresh water, as well as by the level of afforestation of the territory, our country is on the last place in Europe [10].

Trends in climate change over the past 30 years have led to an increase in the level of its continent and complicate the provision of water to the regions.

An important part of the water is constantly as a result of the cycle in the atmosphere of the planet. As a result of evaporation from the surface of the oceans, rivers, lakes and sushi in the atmosphere, every year comes about 525 thousand $\mathrm{km} 3$ of water. [11]

Almost $86 \%$ of the total volume of water entering the atmosphere of the planet is water from the oceans and seas. Accordingly, 73.5 thousand $\mathrm{km} 3$ are volumes of evaporation from the surface of the land. Of these, almost $36,000 \mathrm{~km} 3$ is the volume of water entering the air as a result of processes of thermoregulation of plants - transpiration.

A significant part of water is constantly in the result of the cycle in the atmosphere of the planet. In the form of vapor in the air, there are about 14 thousand $\mathrm{km} 3$ of water. [12]. Above every square meter surface in the surface layer of the atmosphere (troposphere, up to $10 \mathrm{~km}$ ) at a temperature of $20^{\circ} \mathrm{C}$ and relative humidity of 30 and $70 \%$ in the form of gas (steam) is about 52 and 121 liters of water respectively, that is, under conditions of its complete condensation on the surface of the earth it would be a layer of water at a height of 52 and $121 \mathrm{~mm}$.

Similar calculations are relative, since with an increase for every 1000 meters the air temperature is reduced by an average of $6,7 \mathrm{OC}$ and the ability of the air to retain moisture changes [13]. Water reservoirs in the atmosphere are able to fluctuate significantly. Accordingly, the possibility of precipitation of part of the troposphere in the form of rain, snow or hail changes in a significant range

The constant flow of solar radiation and the transformation of its part after absorption by the nontransparent surface into thermal (infrared radiation) provides the circulation of water, including in the atmosphere. For the evaporation of water is almost $20 \%$ of the total energy of the sun entering the planet in the form of rays and absorbed by an opaque surface. The other part of the sun's rays reflects the surface again into space and dissipates [14]. Only a small fraction of the radiant energy $(0.5-1.5 \%)$ can be used by green plants for the needs of photosynthesis.

The absorbed and transformed into the heat energy of light provides formation of the corresponding temperature regime of the region, and has a direct influence on the volumes of water consumption by plants, the formation of wind, and the evaporation and transpiration of moisture by the surface of the soil and plants. $[15,16,17]$.

That is, the very energy (thermal) regime of the region determines the size of atmospheric pressure, wind force, the level of relative humidity and the probability of precipitation [18].

The practice of conducting economic activity, including in the agrarian sector, indicates a significant human impact on the energy balance (albedo) of the region and on the mode of natural humidification of arable land.

With the growth of the degree of plowing of the territory, the destruction of forest plantations, the degradation of rivers and reservoirs, the share of absorption of the incident stream of radiation energy of the Sun increases, and accordingly the proportion of its reflection is reduced [19, 20].

The total amount of heat in the region increases, and the volume of evaporation and transpiration respectively increases, and plants become more in need of fresh water available to them. In the water balance of the regions tensions are increasing. The country's regions for the normal functioning of nature and the economy require the availability of more and more volumes of high-quality fresh water, both for the needs of the population and for irrigation of crops [21]. On average, to provide one inhabitant of the planet in accordance with modern costs of fresh water, it is necessary almost $8000 \mathrm{~m}$ per year.

As traditionally in the Steppe area, and in Polissia, where moisture has been sufficient in recent times, the frequency and duration of drought is now increasing [22]. Problems of maximum accumulation, conservation and rational use of water become actual in practically all over the country.

Results and discussion. 
Approaches to solving such a complex problem can be different. Without dwelling on the possibilities and prospects of irrigation development, we will also recall other ways to influence the water balance of the regions. These include regulation (primarily reducing) the speed of the surface air layer, the formation of a favorable microclimate for agricultural crops, the creation of reservoirs, and the revival of small rivers, the formation of sufficient areas of forest plantations, especially in the zone of the Steppe and Foreststeppe, etc. All they are relevant and deserve a deep scientific development and implementation in practice in the regions.

Consider the possibility of an unconventional way of getting fresh water, especially for regions where there are no powerful and environmentally sound water arteries and where to lay water pipes or channels is expensive and not promising.

Most regions of the country receive water from the atmosphere as a result of the advection (transfer) of water vapor from ocean and sea spaces and the surface of fresh water to the depths of the continent and its loss in the form of rain or snow.

In the surface layer of the atmosphere, to a height of $5-10 \mathrm{~km}$ there is always water and wind. At a temperature of $20^{\circ} \mathrm{C}$ in one $\mathrm{m} 3$ of air can be at a relative humidity of $30 \%-5,2 \mathrm{~g}$, and for $70-112 \mathrm{~g}$ of steam in the form of water.

If this air is cooled at $10^{\circ} \mathrm{C}$, then, according to the "dew point" (condensation of a portion of the vapor into a liquid), it allows one and a half $\mathrm{m} 3$ of air to receive, respectively, 2.4 and $5.5 \mathrm{~g}$ of liquid water.

The surface air layer is almost never stationary. For most regions, the traditional average wind speed within the range of $3-6 \mathrm{~m} / \mathrm{sec}$. That is, if you take 1 to $1 \mathrm{~m}$ above the area in one $\mathrm{m} 2$ moves from 180 to $360 \mathrm{~m} 3$ of air per minute, per hour 10800 and $21600 \mathrm{~m} 3$ of air, for 10 hours, respectively 108000 and $216000 \mathrm{~m} 3$.

Above an area of one $\mathrm{m}^{2}$ surface of the land to a height of 1 meter with air will be transferred at a relative humidity of $30 \%$ for an hour of $56.2 \mathrm{I}$ and $70 \%$ humidity, respectively 112.3 I water. Of these, cooling by $10^{\circ} \mathrm{C}$ in the form of a condensate (liquid) at relative humidity of $30 \%$ will pass 25.9 l per hour, and at a relative humidity of $70 \%$, respectively, 118.8 I per hour.

Within 10 hours above the surface of $1 \mathrm{~m} 2$ up to a height of 1 meter it is possible to condense with relative humidity of $30 \%$ and cooling it to $10 \mathrm{oC}$ to $0,26 \mathrm{t}$ of water, and with a relative humidity of $70 \%$, respectively, $1,19 \mathrm{t}$ of water. If these volumes are translated into $\mathrm{mm}$, then the $\mathrm{m} 2$ of the surface will be the height of the water layer $260 \mathrm{~mm}$ and $1119 \mathrm{~mm}$.

As it was noted, real calculations of the relative humidity of the air and the height of the air layer in one meter over the surface area of one $\mathrm{m} 2$ were used for calculations.

From the above calculations, it is right to assert that the advection (transfer) of large volumes of water in the form of steam constantly occurs above the surface of the air in the air, and condensation of even a very small part of it in the liquid can have not only a theoretical but also a practical perspective.

However, the presence of water in the air requires an estimate of the amount of energy costs for the condensation process of such a volume of water which is included in the calculations.

Taking into account the fact that the air density is 770 times less than water, we will only take into account the heat capacity of the water in the calculation.

For cooling $1 \mathrm{~g}$ of water at $1 \mathrm{OC}$ it is necessary to spend 1 calorie of energy (frigoria). Accordingly, for cooling $1 \mathrm{~g}$ of water at $100 \mathrm{C}$, it is necessary $10 \mathrm{kcal}$. (frigoria) of energy. To cool 562 liters. The water that is present in the air, at a relative humidity of $30 \%$ and its transfer to a relative humidity of $100 \%$ (dew point) should be spent 562k. kal. (frigoria). And for cooling $1123 \mathrm{l}$ of water at a relative humidity of $70 \%$ it is necessary $11230 \mathrm{k}$. kal (frigoria) of energy. As a result of cooling the air at $10^{\circ} \mathrm{C}, 0.26$ and 1.19 tons of water passes into the liquid state, respectively.

At the same time, as a result of the phase transition of water gas (vapor) into a liquid in accordance with the second law of thermodynamics and the law of Clausius-Clayperon, hidden thermal energy (exothermic process) is isolated. For every gram of water condensed from a vapor (gas), $2257 \mathrm{~J}$ of energy is emitted or 539 cal. heat 
Under condensation conditions 0,26t. the liquid will be allocated $140140 \mathrm{kcal}$. heat, and for condensation 1.19 tons of liquid, respectively $641410 \mathrm{kcal}$.

Dedicated as a result of the phase transition of gas (vapor) to the liquid, the thermal energy must be compensated by appropriate cooling. Therefore, the total energy consumption for condensation and phase transition of water in volume $0,26 \mathrm{t}$. the fluids will be $140140+562=140702 \mathrm{kcal}$. (frigoria) of energy.

For condensation of water in the volume of $1.19 \mathrm{t}$ total energy consumption will be $641410+11230=$ $652640 \mathrm{k} . \mathrm{kg}$ (frigoria) of energy, respectively.

To receive one $\mathrm{m} 3$ of liquid water (or one ton of) from atmospheric air it is necessary to spend 54,8437 calories. of energy equivalent to the energy value of $53.2 \mathrm{~kg}$ of diesel fuel.

The energy costs can be significantly lower when used for cooling air with low temperature liquid water. These can be deep water from seas or reservoirs, and wells. In heat exchangers, cooled air condenses part of the moisture in it and returns to the atmosphere. Relatively warm salt water returns to the sea, and the resulting fresh air condensate goes to practical use.

Atmospheric condensate is environmentally clean with pure water. Such water, after proper preparation and balancing of salt content, can be ready for use by the population.

The resulting water can be used to reduce the level of salinity of available water from the reservoirs by its dilution to a concentration of $1-1,500$ and the subsequent use for irrigation of crops of vegetable crops, vineyards, gardens, etc.

Atmospheric condensate - water is devoid of organic impurities and can be well preserved in appropriate reservoirs: tanks, reservoirs, etc., until the time of its use.

Accordingly, the cost of the received $\mathrm{m} 3$ of water (liquid), which is practically devoid of salts, will consist of energy consumption for cooling air + expenses for the work of the system of air fans.

The calculations prove that such a non-standard way of obtaining high-quality water can be quite real. Getting water from the air is possible all year round, but most rationally in the autumn period and in the first half of spring. It is precisely in those days of the year, in relatively warm weather, the air can hold enough water vapor and have a high level of relative humidity.

In the winter, the temperature of the air is relatively low and even with a high level of relative humidity the volume of the condensed liquid can not be significant.

In the summer months, high air temperatures allow relatively large amounts of water vapor to be kept, however, relative humidity levels are traditionally low, and therefore actual water condensation volumes will be significant only under rainy weather conditions.

The question of getting water from the air is locked in the first place by the availability of sufficient quantities of relatively inexpensive energy. The most promising source of it may be, in the first place, the energy of the Sun. In regions where there is the greatest shortage of water, there is a sufficient amount of such energy. It only needs to be collected and rationally applied in favor of man and nature. The formation of powerful solar power plants on photovoltaic cells can provide the southern regions with the energy and necessary volumes of fresh water of high quality.

\section{Conclusions}

1. Water as a compulsory component of life is unique and irreplaceable. It can not be an alternative, and therefore providing high-quality fresh water of all living things is a very urgent problem that requires research and constructive practical solutions. 
2. The surface air layer, even at a low relative humidity level (30\%) over an area of one meter and at an altitude of one meter above the soil surface per hour, moves in the form of steam from 56.2 to 112.3 I of water (wind speeds of 3 and $6 \mathrm{~m} / \mathrm{sec}$ respectively).

3. To get one $\mathrm{m} 3$ of water (one ton of fluid) by condensing it from atmospheric air, it is necessary to spend about 54,8437 calories. energy equivalent to the energy value of $53.2 \mathrm{~kg}$ of dieselfuel.

4. Energy inputs for water can be reduced several times, with the use of a system of heat exchangers with a low temperature substrate (cold water, rocks, etc.) that effectively absorbs heat from the air and heat the phase transition of steam to the liquid.

\section{References}

1. Lehninger A.L. Principles of Biochemistry The Johns Hopkins University Worth Publishers Inc. 1982, -1056c.

2. Large Encyclopedia of Plants -M .: Olma, Media-Group. 2007, -623p.

3. Dvuvinion P., Tang M. Biosphere and place in it of a person - Moscow: Progress, 1968. - 363c.

4. Kamleshov MM Biotic cycle. -M .: Nauka, -1970, - 410s.

5. Walter I. The History of the Earth and Life. - St. Petersburg: Izd. P.P. Soykina, -1911, -537s.

6. Lennarz W.J. The Biochemistry of Glicoproteins and Proteoglycans, Plenum, New York, 1980.

7. Dixon H.H., Atkins W.R.G. Osmatic pressure in plants V. Seasonal variations in the concentration of some decidans and evergreen trees. Scient Proceed royal Dublin soc. 14.p. 455-461 (1915).

8. Forest Encyclopedia - Moscow: "Soviet Encyclopedia" 1985, t.1. -563s.

9.Dick D.A. T. Cell Water, Butterworths, Washington, 1966.-364c.

10. Eisenberg D., Kausmann W. The Structure and Properties of Water, Oxford University Press, Fair Lawn, N.J. 1969

11. Yamada K. M., Olben K. Fibronectins, Abhesive Glicoproteins of Cell Surface and Blood. Nature, 275. 179-184 (1978).

12. Climate of Ukraine for ed. VM Lipinsky, V.A. Diachuka, V.M. Babichenko -K .: Kind. Rajewski, 2003. - 332c.

13. Small Mining Encyclopedia in 3 volumes. Ed. VS Biletsky - Donetsk Oriental Publishing House. 2004-2013. - 1560s

14. Solomon A.K. The State of Water in Red Cells, Science Am. -244. -88-96. February (19710.

15. Brant AV, Tageeva SV Optical parameters of plant organisms. -M .: Science. 1997. -300s.

16. Dadykin VP, Bedenko VP, Davydova Yu.L. On the dependence of optical properties of leaves of plants on soil fertilization. // DAN of the USSR. -1989 -t 128 No. 6. -with. 1305-1309.

17. Zlobin Yu.A., Sukhoi I.B. Coefficients of spectral reflection of woody and herbaceous plants. // Journal of General Biology. 1998. -T. XL.VII №4 -s. 520-528.

18. Water for people - water for life. - UN report on the state of water resources of the world. $-\mathrm{M}$.: Progress, -2003, - 67s.

19. Khilchevsky V.K. Osadchy VI Kuril S.M. Fundamentals of Hydrochemistry -K .: Nika-Center. 2012. $-312 p$.

20. Boyko P.I. Crop rotation in agriculture in Ukraine. -K .: Agrarian Science, 2002. -260s.

21. Bourda R.I., Patty V.P. Monitoring phytobiotics of segetal ecosystems // Bulletin of agrarian science. 2002.-№6. -S.59-63.

22. Danilov - Dinilian V.N. Global problems of fresh water deficit // The age of globalization - 2008.№1. - with. 45-56. 